\title{
Xp11.2 translocation renal cell carcinoma with TFE3 gene fusion: A case report
}

\author{
XIANG PAN $^{1,2^{*}}$, JING QUAN $^{1,2^{*}}$, LIWEN ZHAO $^{1,2}$, WENHUA LI $^{1}$, \\ BENLIN WEI $^{1}$, SHANGQI YANG ${ }^{1}$ and YONGQING LAI ${ }^{1}$ \\ ${ }^{1}$ Department of Urology, Peking University Shenzhen Hospital, Shenzhen, Guangdong 518036; \\ ${ }^{2}$ The First Clinical College, Anhui Medical University, Hefei, Anhui 230032, P.R. China
}

Received July 13, 2017; Accepted October 2, 2017

DOI: $10.3892 /$ mco.2017.1497

\begin{abstract}
Xp11.2 translocation renal cell carcinoma (RCC) with transcription factor E3 (TFE3) gene fusion is a rare tumor, and the prognosis of this tumor is poorer compared with that of other subtypes of RCC. The patient presented herein was a 70-year-old man who presented with a solid mass sized $\sim 8.2 \times 6.1 \mathrm{~cm}$ in the right kidney and underwent radical right nephrectomy. Following pathological and immunohistochemical (IHC) examination and fluorescent in situ hybridization (FISH), the patient was diagnosed with Xp11.2 translocation RCC with TFE3 gene fusion. These tumors are more commonly encountered in children rather than in adults, and adult Xp11.2 translocation RCC is associated with a poorer prognosis compared with its pediatric counterpart. IHC assay and FISH are important diagnostic methods. However, there is currently no established effective treatment for Xp11.2 RCC.
\end{abstract}

\section{Introduction}

The most common type of kidney cancer is renal cell carcinoma (RCC), constituting $\sim 85 \%$ of malignant renal tumors and 3-6\% of all adult malignancies (1). RCC is a heterogeneous malignancy, the most common histological subtypes being clear-cell (60-75\%), papillary (10-15\%), chromophobe (5\%), and collecting duct carcinoma, each of which are associated with specific histopathological and genetic characteristics. In the 2004 World Health Organization renal tumor classification, the $\mathrm{Xp11.2}$ translocation RCC with TFE3 gene fusion is described as a distinct entity (2). Furthermore, Xp11.2 translocation RCCs have been reported as being more aggressive and having a

Correspondence to: Professor Yongqing Lai, Department of Urology, Peking University Shenzhen Hospital, 1120 Lianhua Road, Shenzhen, Guangdong 518036, P.R. China

E-mail: yqlord@163.com

*Contributed equally

Key words: renal cell carcinoma, Xp11.2, transcription factor E3 gene fusion poorer prognosis compared with other subtypes of RCC (3). In addition, Xp11.2 translocation RCCs are generally considered a pediatric cancer, accounting for $20-40 \%$ of pediatric RCCs and only $1-1.6 \%$ of adult RCCs $(4,5)$. In addition, adult Xp11.2 translocation RCC has a poorer prognosis compared with its pediatric counterpart (6). This type of RCC is generally characterized by a range of translocations on chromosome Xp11.2 leading to a gene fusion between TFE3 and at least 6 possible partners (7). The diagnosis of Xp11.2 translocation RCC is based on fluorescent in situ hybridization (FISH) rather than histological characteristics and imaging examination (8). The majority of patients with Xp11.2 translocation RCC present at a more advanced stage compared with conventional RCC (9). Surgical resection is considered as the most effective method for the treatment of Xp11.2 translocation RCC.

We herein report a rare case involving an elderly patient with Xp11.2 translocation RCC with TFE3 gene fusion, and review the relevant literature.

\section{Case report}

A 70-year-old man was diagnosed with a solid mass in the right kidney during a routine health examination and consulted a doctor at the Department of Urology, Peking University Shenzhen Hospital (Shenzhen, China) on June 9, 2015. The patient was healthy prior to the discovery of the tumor, and he had no surgical history, no family history of cancer, and no history of smoking or drinking. The routine blood tests were normal. A computed tomography scan revealed a solid mass in the right kidney, sized $6.1 \times 5.6 \times 8.2 \mathrm{~cm}$ (Fig. 1).

As there were no contraindications to surgery, the patient underwent radical right nephrectomy on June 15, 2015. The surgery was successful, and the size of excised kidney was $8 \times 13.5 \times 6.5 \mathrm{~cm}$. On pathological examination, a proportion of the tumor cells were arranged in nests and had a clear cytoplasm, whereas the remaining cells were arranged in a papillary pattern and had eosinophilic cytoplasm (Fig. 2). The immunohistochmical (IHC) examination revealed that CD10 and CK8/18 were negative and TFE3 was positive (Fig. 3A). FISH analysis revealed positive TFE3 translocation in the tumor cells (Fig. 3B).

After the surgery, the patient was treated with intravenous fluid therapy and pain relief medication. The patient had an 
uneventful postoperative recovery and was discharged from the hospital after 2 weeks. However, he succumbed to cancer recurrence 1 year later.

\section{Discussion}

$\mathrm{Xp} 11.2$ translocation RCC with TFE3 gene fusion is a rare tumor, and adult Xp11.2 translocation RCC has a poorer prognosis compared with its pediatric counterpart. The aim of the present study was to report a rare case involving an elderly patient with Xp11.2 translocation RCC with TFE3 gene fusion of the right kidney and review the relevant literature to help elucidate the characteristics of this rare type of cancer.

Xp11.2 RCC with TFE3 gene fusion has at least 5 fusion partners, including ASPL-TFE3, PSF-TFE3, CLTC-TFE3, PRCC-TFE3 and Nono-TFE3, with the chromosomal rearrangements $\mathrm{t}(\mathrm{X} ; 17)(\mathrm{p} 11.2 ; \mathrm{q} 25), \mathrm{t}(\mathrm{X} ; 1)(\mathrm{p} 11.2 ; \mathrm{p} 34), \mathrm{t}(\mathrm{X} ; 17)$ $(\mathrm{p} 11.2 ; \mathrm{q} 23), \mathrm{t}(\mathrm{X} ; 1)(\mathrm{p} 11.2 ; \mathrm{q} 21)$ and $\operatorname{inv}(\mathrm{X})(\mathrm{p} 11.2 ; \mathrm{q} 12)$, respectively $(10,11)$. Sidhar et al were the first to describe this rare cancer (12), and the World Health Organization recognized it as a distinct entity in 2004 (2). The different gene fusions may be associated with different clinical and morphological characteristics (13). As these translocations are located on the $\mathrm{X}$ chromosome, it would appear reasonable to expect gender differences in this rare cancer; however, there is a insufficient evidence to support this hypothesis.

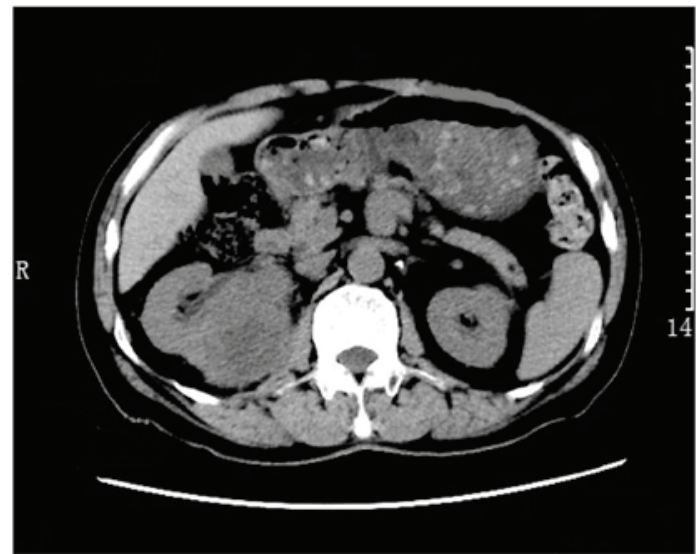

Figure 1. The computed tomography scan revealed a solid mass in the right kidney, sized $6.1 \times 5.6 \times 8.2 \mathrm{~cm}$.

Xp11.2 translocation RCC exhibits different morphological characteristics similar to clear-cell RCC and papillary renal cancer (14). The typical morphology includes nested or papillary architecture, with cells with voluminous, clear or eosinophilic cytoplasm.

The most common diagnostic method of Xp11.2 translocation RCC with TFE3 gene fusion is IHC assay using an antibody for the C-terminal portion of TFE3 (15), as this cancer involves TFE3 protein overexpression. However, recent

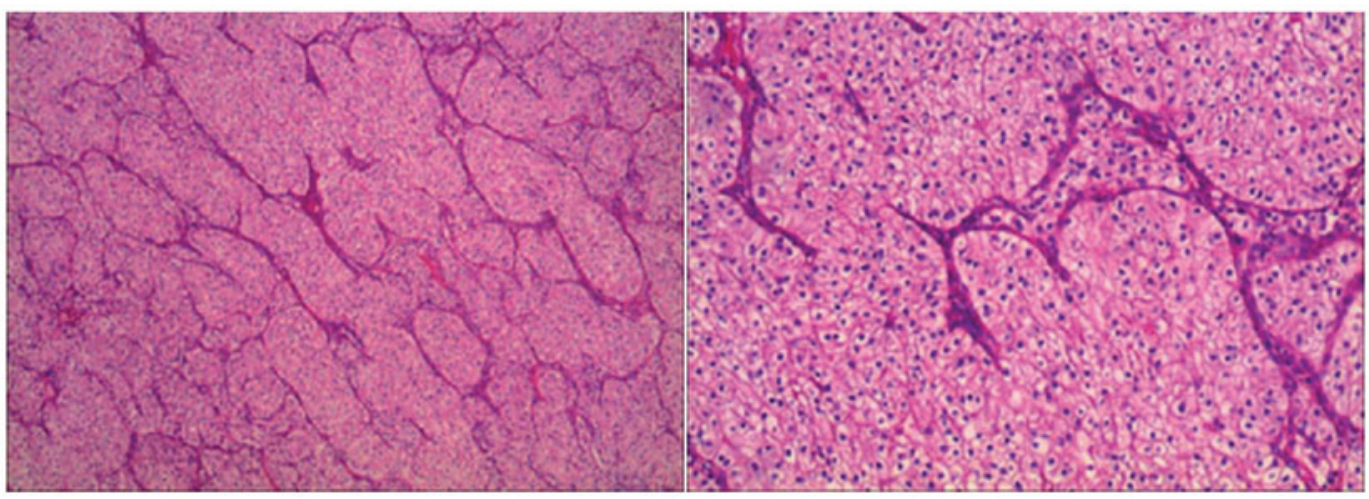

Figure 2. Some of the tumor cells were arranged in nests and had clear cytoplasm, whereas the others were arranged in papillary formations and their cytoplasm was eosinophilic. Hematoxylin and eosin staining; magnification, left panel x40 and right panel x200.

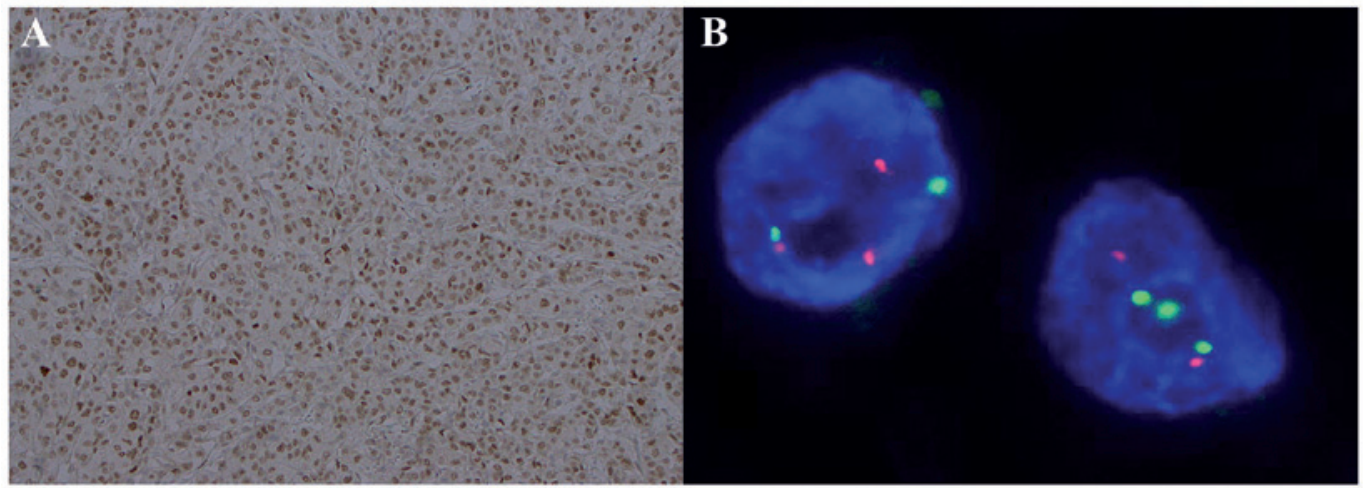

Figure 3. (A) The immunohistochemical examination revealed positivity for transcription factor E3 (TFE3). (B) fluorescent in situ hybridization analysis was positive for TFE3 translocation in the tumor cells. 
studies have reported that IHC for TFE3 is associated with a high rate of false-positive results (16). Thus, the genetic identification of this rare cancer using FISH is an important diagnostic method (7).

Xp11.2 translocation RCC mostly affects children, accounting for $20-40 \%$ of pediatric RCCs and only $1-1.6 \%$ of RCCs in adults $(4,5)$. However, as the overall incidence of $\mathrm{RCC}$ has increased, the Xp11.2 translocation RCC in adults has become more common. It has been reported that Xp11.2 translocation RCC in adult patients may be associated with advanced stage at diagnosis and an aggressive clinical course, with a poor prognosis (17). Srigley et al reported the adult patients have a mean survival of up to 2 years, whereas the mean survival in pediatric patients is 6.3 years (7). Furthermore, it has been reported that $\sim 15 \%$ of the adult patients with Xp11.2 translocation RCC had a history of chemotherapy; thus, the occurrence of this cancer may be correlated with chemotherapy (7).

The treatment for Xp11.2 RCC varies; however, there has been no established effective treatment to date. The most common treatment of Xp11.2 RCC is similar to that for conventional RCC. For localized Xp11.2 RCC with positive regional lymph nodes, surgery is the optimal treatment (18). If the tumor is sized $<7 \mathrm{~cm}$, nephron-sparing surgery is considered as a treatment option (19). Immunotherapy may be beneficial for patients who have hematogenous metastases, including multikinase inhibitors, interleukin- 2 and interferon- $\alpha$. Recent studies suggested that mammalian target of rapamycin inhibitors may be effective for Xp11.2 translocation $\operatorname{RCC}(12,20)$. Moreover, targeted agents, such as sunitinib, sorafenib and everolimus, have also been applied (21).

\section{Acknowledgements}

The present study was supported by the National Natural Science Foundation of China (grant no. 81101922), the Science and Technology Development Fund Project of Shenzhen (grant nos. JCYJ20150403091443329 and JCYJ20170307111334308), the fund of 'San-ming' Project of Medicine in Shenzhen, and the fund of Guangdong Key Medical Project.

\section{References}

1. Verhoest G, Veillard D, Guillé F, De La Taille A, Salomon L, Abbou CC, Valéri A, Lechevallier E, Descotes JL, Lang H, et al: Relationship between age at diagnosis and clinicopathologic features of renal cell carcinoma. Eur Urol 51: 1298-1304, 2007.

2. Bruder E, Passera O, Harms D, Leuschner I, Ladanyi M, Argani P, Eble JN, Struckmann K, Schraml P and Moch H: Morphologic and molecular characterization of renal cell carcinoma in children and young adults. Am J Surg Pathol 28: 1117-1132, 2004.

3. Qiu Rao, Bing Guan and Zhou XJ: Xp11.2 translocation renal cell carcinomas have a poorer prognosis than non-Xp11.2 translocation carcinomas in children and young adults: A meta-analysis Int J Surg Pathol 18: 458-464, 2010.

4. Kmetec A and Jeruc J: Xp 11.2 translocation renal carcinoma in young adults; recently classified distinct subtype. Radiol Oncol 48: 197-202, 2014

5. Komai Y, Fujiwara M, Fujii Y, Mukai H, Yonese J, Kawakami S, Yamamoto S, Migita T, Ishikawa Y, Kurata M, et al: Adult Xp11 translocation renal cell carcinoma diagnosed by cytogenetics and immunohistochemistory. Clin Cancer Res 15: 1170-1176, 2009.

6. Argani P and Ladanyi M: Translocation carcinomas of the kidney. Clin Lab Med 25: 363-378, 2005.
7. Klatte T, Streubel B, Wrba F, Remzi M, Krammer B, de Martino M, Waldert M, Marberger M, Susani M and Haitel A: Renal cell carcinoma associated with transcription factor E3 expression and Xp11.2 translocation: Incidence, characteristics, and prognosis. Am J Clin Pathol 137: 761-768, 2012.

8. Srigley JR, Delahunt B, Eble JN, Egevad L, Epstein JI, Grignon D, Hes O, Moch H, Montironi R, Tickoo SK, et al: The international society of urological pathology (ISUP) vancouver classification of renal neoplasia. Am J Surg Pathol 37: 1469-1489, 2013.

9. Sukov WR, Hodge JC, Lohse CM, Leibovich BC, Thompson RH, Pearce KE, Wiktor AE and Cheville JC: TFE3 rearrangements in adult renal cell carcinoma: Clinical and pathologic features with outcome in a large series of consecutively treated patients. Am J Surg Pathol 36: 663-670, 2012.

10. Wang W, Ding J, Li Y, Wang C, Zhou L, Zhu H and Peng W: Magnetic resonance imaging and computed tomography characteristics of renal cell carcinoma associated with Xp11.2 translocation/TFE3 gene fusion. PLoS One 9: e99990, 2014.

11. Liu K, Xie P, Peng W and Zhou Z: Renal carcinomas associated with Xp11.2 translocations/TFE3 gene fusions: Findings on MRI and computed tomography imaging. J Magn Reson Imaging 40: 440-447, 2014.

12. Ellati RT, Abukhiran I, Alqasem K, Jasser J, Khzouz J, Bisharat T, Al-Saidi I and Al-Daghmin A: Clinicopathologic features of translocation renal cell carcinoma. Clin Genitourin Cancer 15: 112-116, 2017.

13. Rao Q, Williamson SR, Zhang S, Eble JN, Grignon DJ, Wang M, Zhou XJ, Huang W, Tan PH, Maclennan GT and Cheng L: TFE3 break-apart FISH has a higher sensitivity for Xp11.2 ranslocation-associated renal cell carcinoma compared with TFE3 or cathepsin $\mathrm{K}$ immunohistochemical staining alone: Expanding the morphologic spectrum. Am J Surg Pathol 37: 804-815, 2013

14. Rao Q, Chen JY, Wang JD, Ma HH, Zhou HB, Lu ZF and Zhou XJ: Renal cell carcinoma in children and young adults: Clinicopathological, immunohistochemical, and VHL gene analysis of 46 cases with follow-up. Int J Surg Pathol 19: 170-179, 2011.

15. Dey B, Badhe B, Govindarajan KK and Ramesh RA: Xp11.2 translocation renal cell carcinoma diagnosed by immunohistochemistry and cytogenetics. J Lab Physicians 8: 123-125, 2016.

16. Green WM, Yonescu R, Morsberger L, Morris K, Netto GJ, Epstein JI, Illei PB, Allaf M, Ladanyi M, Griffin CA and Argani P: Utilization of a TFE3 break-apart FISH assay in a renal tumor consultation service. Am J Surg Pathol 37: 1150-1163, 2013.

17. Xu L, Yang R, Gan W, Chen X, Qiu X, Fu K, Huang J, Zhu G and Guo H: Xp11.2 translocation renal cell carcinomas in young adults. BMC Urol 15: 57, 2015.

18. Ahluwalia P, Nair B and Kumar G: Renal cell carcinoma associated with Xp11.2 translocation/TFE3 gene fusion: A rare case report with review of the literature. Case Rep Urol 2013: 810590, 2013.

19. Song HC, Sun N, Zhang WP, He L, Fu L and Huang C: Biological characteristics of pediatric renal cell arcinoma associated with Xp11.2 translocations/TFE3 gene fusions. J Pediatr Surg 49: 539-542, 2014.

20. Kakoki K, Miyata Y, Mochizuki Y, Iwata T, Obatake M, Abe K, Nagayasu T and Sakai H: Long-term treatment with sequential molecular targeted therapy for Xp11.2 translocation renal cell carcinoma: A case report and review of the literature. Clin Genitourin Cancer 15: e503-e506, 2017.

21. Sudour-Bonnange H, Leroy X, Chauvet MP, Classe M, Robin PM and Leblond P: Cutaneous metastases during an aggressive course of Xp11.2 translocation renal cell carcinoma in a teenager. Pediatr Blood Cancer 61: 1698-1700, 2014. 